\title{
DELIMITING THE CONCEPT OF ORGANIZATIONAL COMMITMENT: EMPIRICAL EVIDENCE OF THE OVERLAP BETWEEN THE ENTRENCHMENT AND THE CONTINUANCE MINDSET
}

\author{
Delimitando o conceito de comprometimento organizacional: evidências empíricas \\ de sobreposição entre 0 entrincheiramento e a base de continuação
}

Ana Carolina de Aguiar Rodrigues*

Antônio Virgílio Bittencourt Bastos**

Daniela Campos Bahia Moscon ${ }^{\star * \star}$

\section{ABSTRACT}

In the research agenda on organizational commitment, the three-dimensional model of Meyer and Allen is still extensively used, despite the fact that it has been the focus of discussions about conceptual and empirical problems, especially those related to one of its dimensions (continuance commitment). This study introduces to the existing debate the concept of organizational entrenchment, as the worker's tendency to remain due to his evaluation of his employability, his employment alternatives outside the organization, and the costs associated with leaving the company. In the career field, researchers found evidence of overlap between entrenchment and continuance commitment. In this study, we aimed to test the hypothesis of overlap between these constructs within the organizational target, using structural equation modeling. The sample consisted of 721 workers from different organizations and states in Brazil. We used SPSS 13.0 and AMOS 16.0 software. The two covariance models, both with good fit indices, provided evidence of overlap. In spite of the fact that the hypothesis was confirmed, we recommend further studies aimed at gathering additional empirical indicators showing that

\section{RESUMO}

Na pesquisa sobre comprometimento organizacional predomina o modelo tridimensional de Meyer e Allen que tem sido foco de discussões acerca de possíveis inconsistências, especialmente relacionadas à sua base de continuação. Assim, o presente estudo coloca em pauta o conceito de entrincheiramento organizacional como a tendência do trabalhador a permanecer devido à avaliação acerca de sua empregabilidade, de suas alternativas fora da organização e dos custos associados à sua saída. No campo das carreiras foram reunidas evidências de sobreposição entre o entrincheiramento e comprometimento de continuação. Testou-se a hipótese de sobreposição dos construtos com foco organizacional a partir da avaliação de modelos estruturais de covariância. A amostra do estudo contemplou 721 trabalhadores de diferentes organizações e estados do Brasil. Foram utilizados os softwares SPSS 13.0 e AMOS 16.0 e empregada a modelagem de equações estruturais. Os testes de covariância entre os construtos, ambos com bons índices de ajuste, resultaram nas primeiras evidências de sobreposição. Apesar da confirmação do teste da hipótese, recomenda-se outras investigações

\footnotetext{
* Professor in the area of People Management in Organizations in the Administration Department of the School of Economics, Administration and Accounting - University of São Paulo. PhD in Psychology by the Federal University of Bahia (UFBA). Email: anacarolina.ar@usp.br. ORCID: 0000-0002-5539-8541

** Professor in the area of Social Psychology of Organizations in the Institute of Psychology at the Federal University of Bahia (UFBA). Area coordinator at Capes (2011-2018). CNPq I-A Researcher. Holds a PhD in Psychology by the University of Brasília. Email: antoniovirgiliobastos@gmail.com. ORCID: 0000-0002-1322-5749

*** Professor of the Graduate Program in Administration of the University of Salvador-Bahia (PPGA - Unifacs). Holds a PhD in Administration by the Federal University of Bahia (UFBA). Email: daniela.moscon@unifacs.br. ORCID: 0000-0002-2933-2880
} 
the continuance component represents the same phenomenon as organizational entrenchment, justifying its detachment from the concept of commitment.

Keywords: Continuance Commitment; Organizational Entrenchment; Conceptual and Empirical Overlap. que permitam reunir uma base empírica que suporte a defesa de que a dimensão de continuação representa o mesmo fenômeno constituído pelo entrincheiramento organizacional, justificando sua desintegração do conceito de comprometimento.

Palavras-chave: Comprometimento de continuação; Entrincheiramento organizacional; Sobreposição conceitual e empírica.

\section{HISTORICAL REVIEW OF THE CONCEPTUAL PROBLEMS OF COMMITMENT AND THE NEED TO ENHANCE ITS DELIMITATION}

$\Omega^{8}$ ommitment is a concept of such theoretical and practical relevance that its studies go back almost sixty years, and extend to different countries, on different continents, and is the main type of attachment to work that has been studied, both in Brazil and internationally (BASTOS et al., 2013). Despite this, it is still not possible to present a clear and straightforward definition of commitment. Its development was marked, from the beginning, by warnings from authors who already glimpsed the problems that would threaten the validity and trustworthiness of future studies: overly broad expansion of its conceptual extent that, while it grew, it diverged from the schemes presented by organizational actors, for the same phenomenon. Reichers (1985) pointed out researchers' lack of care in understanding the organizational actors' perceptions and expectations regarding commitment, since the concepts proposed were usually derivations of and additions to previous definitions. His criticism was supported, especially, by the movement of researchers who proposed, at the time, new dimensions and new scales for commitment (ALUTTO et al., 1973; BUCHANAN, 1974; ETZIONI, 1961/1974; KANTER, 1968; O'REILLY; CHATMAN, 1986).

Osigweh (1989), also mindful of this trend, alerted about the risks of proposing wide-ranging constructs and measures, since the inclusion of too many concepts could, instead of broadening the reach of the constructs, threaten the precision of the studies conducted and consequently their scientific validity. Given the predominance of studies on worker bonds, commitment, which had initially been proposed from a one-dimensional affective perspective, evolved into multidimensional models in order to incorporate different psychological bases into a single concept. Among these multidimensional models, researchers turned to the general use of the Meyer and Allen (1991) three-dimensional model, proposed on the basis of previously studied psychological bases: the affective, expressed by identification and affection towards the organization (MOWDAY et al., 1982); the normative, result of the internalization of organizational values and norms that generate the feeling of obligation to remain (WIENER, 1982); and that of continuance, based on an instrumental rationality that calculates the costs involved and the benefits lost in leaving the organization (BECKER, 1960). 
This type of inclusive perspective, which seeks to include all the expectations of what the phenomenon might involve in the same conceptual structure, generated theoretical fragmentations and inaccuracies for the research agenda on commitment (RODRIGUES; CARVALHO-FREITAS, 2016). Authors have come to see how different types and natures of bonds have been implicitly included under the conceptual umbrella of commitment (KLEIN et al., 2012; BASTOS et al., 2014). In the specific case of the three-dimensional model, although still widely used today, it cannot be considered consensual. In fact, the growth of disagreements on the dimensionality of commitment has recently resulted in the chapters by Klein and Park (2016) and Allen (2016), which discuss one-dimensional and multidimensional approaches in a handbook organized by Meyer (2016). In other words, the area recognizes the debate and understands it as still unresolved. This also explains why defining commitment at work is not a simple task. Klein (2013) and Rodrigues and Bastos (2010) used content analysis on the definitions of commitment in the literature and reached the same conclusion: redundancy and imprecision of the approaches.

Moreover, for a more precise definition and operationalization of commitment, Klein et al. (2014) propose a new one-dimensional scale, called KUT - Unidimensional, Target-Free (Klein et al., 2014), with an emphasis on the same essence of the affective basis and on the volitional character of the bond. That is, they eliminate presence by necessity (which characterizes the continuance basis) and presence by obligation (which characterizes the normative basis). They point out that these two notions would be types of psychological ties (acquiescence, instrumentality) treated in the literature under the label of commitment when, in reality, they should be treated on the basis of specific concepts. Rodrigues and Bastos (2010) have already argued that these bases derive from different types of antecedents and provoke equally diverse effects both on the worker and on the employer organization.

Adhering, therefore, to the one-dimensional perspective of commitment, this paper seeks to offer additional support for the removal of the continuance component, because it carries and provokes the greatest number of theoretical and empirical inconsistencies in research on organizational commitment.

\subsection{THE PLACE OF THE INSTRUMENTAL NATURE IN STUDIES ON BONDS}

Conceptually, continuance commitment includes the idea of permanence by necessity. Here it is worth recalling that commitment has been under study for almost sixty years. This means that permanence was a major concern at the time when studies began in this area, having led researchers to attempt to investigate the link that differentiated workers that were leaving from those who remained (PORTER et al., 1974). Today, however, different motives point to going beyond the notion of permanence embedded in the concept of commitment: this is no longer the main concern of organizations and workers, since active contributions are increasingly expected instead of passive continuity (RODRIGUES; BASTOS, 2010); permanence has been treated more as a possible consequence of commitment than as a condition for the bond (KLEIN et al., 2012); it is clear that other factors may explain the worker's permanence or not (spouse's transfer to another city, for example), many of them independent of the bond established with the organization (KLEIN et al., 2012). 
Solinger et al. (2008) add to this panorama the particularity that the continuance basis represents an attitude whose object is the behavior of remaining, different from the affective attitudinal bond, whose object is the organization. The failure of some studies to identify the relationships between the continuance basis and desired variables is attributed to this difference, since this dimension measures the advantage in remaining, or the non-utility of leaving the organization, due to the costs associated with leaving. Thus, the authors consider it understandable that no significant relationships are found between desirable behaviors, such as organizational citizenship, and the usefulness assessed by the individual in remaining in the organization (continuance commitment).

In addition to this conceptual inconsistency, there are problems related to the psychometric quality of the continuance basis scale. Based on a review of different studies Rodrigues and Bastos (2010) calculated, the mean reliability indices within (0.76) and outside (0.65) of North America. The authors point out that, in addition to the possible cultural factors that affect the reliability of the scale in other countries, the tendency observed in studies with various origins is that the measure of the continuance basis presents more critical results in comparison to the more positive results found for the scale with an affective basis.

Moreover, there are indications that the continuance commitment scale is composed of two sub-dimensions, termed "high personal sacrifice" and "few perceived alternatives" (CARSON; CARSON, 2002). Given this possibility, it is also proposed that the "few alternatives" dimension be treated as an antecedent and not as a component of commitment (CARSON; CARSON, 2002). Beyond its congruence with arguments already discussed here, this suggestion is based on the analysis that the "personal sacrifices" factor better represents the theoretical basis of continuance commitment, which is Becker's (1960) side-bet theory.

The measure's conceptual and psychometric quality problems result in the instability and incongruity of empirical studies. Various studies indicate that the continuance basis presents a pattern of relationships opposite to that observed for the affective and normative bases. Studies report, for example, negative relationships of continuance commitment with antecedents such as perceptions of fairness, organizational support, job satisfaction, and with consequences such as performance and organizational citizenship behaviors. These same variables present positive relationships with the affective and normative bases. On the other hand, undesirable variables, such as role conflict, negligence, and absenteeism, present positive relationships with the continuance basis and, conversely, negative relationships with the other bases (MEYER et al., 2002; COOPER-HAKIM; VISWESVARAN, 2005; KLEIN et al., 2012; MOSCON; BASTOS; JANISSEK-DE-SOUZA, 2012). These results lead us to question whether the continuance basis is actually part of the concept of commitment, and whether the concept shouldn't in fact be treated as a one-dimensional construct, considering the high correlations found between the normative and affective bases (MEYER et al., 2002; POWELL; MEYER, 2004). Klein, Molloy and Brinsfield (2012) highlight the difficulty of developing a valid psychometric measure of an ambiguous construct resulting from contaminated and confusing measures.

Despite all these caveats that call the three-dimensional model into question, more than 150 studies supported by this model were gathered in the meta-analysis conducted by Meyer, Stanley, Herscovitch and Topolnytsky (2002). Thus, the theoretical-empirical delimi- 
tation of the concept of commitment is still a challenge for research in this area. According to the recommendation of Osigweh (1989), a reverse movement must be undertaken in order to remove concepts from the construct that were wrongly included.

Thus, as a way to resolve the place of the continuance basis and its instrumental nature in the studies on bonds, the present study presents and discusses the concept of entrenchment, originated in the career field of study and transposed by Rodrigues and Bastos (2011) into the organizational target.

\section{ORGANIZATIONAL ENTRENCHMENT}

Taking the above arguments about worker permanence in the organization as a starting point, and considering that commitment favors a permanence that is voluntary and therefore related to desirable behaviors, what kind of bond would be established by a worker who remains involuntarily, by necessity? What factors would contribute to this permanence?

In order to answer these questions, Rodrigues and Bastos (2011) have brought to the organizational target the concept of entrenchment, which can be defined as the worker's tendency to remain in the organization due to his assessment of his employability, his alternatives outside the organization, and the costs associated with the possibility of leaving. The theoretical framework of entrenchment was developed from the studies on career, proposed by Carson et al. (1995) based on Becker's (1960) side-bet theory. Becker (1960), one of the first authors to attempt to systematize the concept of commitment, without dwelling on a specific focus, argues that individuals engage in consistent lines of action (side bets) in order to meet cultural expectations, fit into social roles, preserve their self-image, or ensure the maintenance of advantages deriving from certain behaviors. His work became a reference in the studies on attachment to work, although the instrumental reasons for the formation of side bets prevailed in the literature.

Thus, for the conceptualization of entrenchment with a focus on career, Carson et al. (1995) used Becker's (1960) study as a main reference, which inspired the first two dimensions of the proposed construct: investments in career, which are the efforts expended by workers to develop their career, such as money, energy, and time for the necessary learning for their professional growth; and emotional costs, which refer to any costs arising from a career change, such as the interruption of interpersonal relationships. Because of the imprecise quality of what these emotional costs would be, and the similar theoretical basis of both dimensions (side bets), Blau (2001) gathered evidence to support the combination of these factors into a single dimension called accumulated costs. The third factor proposed by Carson et al. (1995) is that of limited alternatives, or the perception that opportunities are restricted outside of one's career, due to the specificity of the knowledge acquired or even the age of the professional.

Regarding its application with an organizational target, the term "entrenchment" had already been mentioned in this sense by Mowday et al. (1982) when, concerned with the concept of commitment, they referred to it as the result of an individual's prolonged presence in the organization, until then attributed to organizational commitment. This long period of employment would lead to a state of entrenchment for various reasons: the investments of 
time and energy made in the company that contribute to attaining more valued positions and rewards, and make it difficult to leave; the social networks formed in the organization, that would be threatened upon leaving; the worker's perception that his profile has become very specific to that organization and is no longer easily transferable to other situations; and the justifications formulated by individuals for the investments and sacrifices made by the organization, as a way to avoid cognitive dissonance.

Thus, in order to make the organizational entrenchment concept operationally feasible, Rodrigues and Bastos (2012) collected items based on the review of these studies, as well as items from existing scales, that sought to measure side bets or explain the permanence of the individual in the organization. The validation process included exploratory and confirmatory analyses, and from the total of 31 items collected, 22 remained after the validation process, which resulted in three factors, described as follows:

- Adjustments to Social Position (ASP; $\alpha=.80$ ): eight items referring to the individual's efforts and investments in the process of adapting to the organization, such as time, acquired knowledge, status attained, and relationship networks formed;

- Impersonal Bureaucratic Arrangements (IBA; $\alpha=.77$ ): seven items related to the costs associated with leaving the organization, for example, loss of financial stability and loss of benefits such as vacations, profit sharing, variable compensation, health and dental care, private pension, and retirement benefits, among others;

- Limited Alternatives (LA; $\alpha=.79$ ): seven items that assess the respondent's perception regarding job opportunities outside the organization in which he works. Since the notion of limited alternatives is also present in the continuance commitment measure, items originally designed to measure this basis were included in the validation of the scale.

Rodrigues and Bastos (2012), in proposing this last dimension, revisit and contrast its pertinence in the continuance commitment scale and the organizational entrenchment scale. They argue that, although it may be considered an antecedent of commitment, as already mentioned, the perception of limited alternatives is a decisive factor in the process of entrenchment.

First, there is a notion of intrinsic limitation embedded in processes that strengthen the other factors. To the extent that individuals feel that they have adhered to a profile overly specific to the organization where they work, or believe that their personal characteristics do not contribute to their employability, or even that their current role and status would not be easily achieved in another organization, they would come to see they have no alternatives that would really allow them to readapt. Likewise, when they attain a standard of benefits or material returns that they deem appropriate or competitive, it becomes more difficult to identify opportunities that offer similar rewards. Second, one can say that the limited alternatives dimension, focused especially on the perception of extrinsic limitations, is fundamental to characterizing the cyclical process of entrenchment: just as the identification of specificities in one's profile makes individuals believe that they will not find alternatives in the market, the initial perception that there are no opportunities outside the organization will likewise serve to strengthen their beliefs that they are already well-adapted to the norms, activities, roles, and rewards of their current job. 
In addition to the theoretical confrontation of the three-dimensional and two-dimensional structures of entrenchment, Rodrigues and Bastos (2012) present the results of the confirmatory analyses of the two alternative models, for comparison purposes. Since both present good fit, they conclude that the three-dimensional structure should remain, and advise that other studies, in this initial phase of the construct development, should be charged with reexamining these structures. The validation of the organizational entrenchment measure opens the way for empirical tests of its overlap with the continuance basis, as is already happening in the field of careers.

\section{EVIDENCE OF OVERLAP BETWEEN ENTRENCHMENT AND THE CONTINUANCE BASIS WITH A CAREER TARGET}

Since it was first proposed with a career target, the concept of entrenchment has been confronted with the concept of commitment, due to the connections observed by different researchers between entrenchment and continuance commitment. This was possible because, years earlier, Meyer et al. (1993) extended the three-dimensional model of commitment, originally proposed with an organizational target, to the field of careers.

Some empirical studies point to similar relationships of entrenchment and continuance commitment with a number of variables. Magalhães and Gomes (2005) found negative relationships between entrenchment and generativity, which consists of the individual's involvement with the well-being of the next generations and the desire to be remembered for the activities developed. They interpret, on the basis of these results, that the state of entrenchment, resulting from the need to remain in their career, reduces the individual's concern with his productivity or with the possibility of contributing, through his work, to future generations. Magalhães (2008) also found negative relationships between career generativity and organizational continuance commitment, which presented positive and significant associations with all the factors of entrenchment, and negative or non-significant ones with the factors of commitment to career, measured by the Carson and Bedeian (1994) scale. The affective and normative bases of organizational commitment, on the other hand, presented positive and significant correlations with all the components of commitment to career and with the "emotional costs" component of entrenchment. Affective commitment also correlated negatively with the "lack of alternatives" dimension. The author concluded that there are two closely tied pairs of meanings, which are commitment to career and the affective basis, and career entrenchment and the continuance basis. In a later study (MAGALHÃES, 2014) he found positive relationships between entrenchment and lack of independence and proactivity, possibly resulting in attachment to the material and social gains achieved, and difficulty in exploring career alternatives and facing the stress and losses inherent in possible changes.

Scheible and Bastos (2014) and Scheible et al. (2013) found results consistent with these studies as they investigated the relationships between entrenchment, commitment, and performance. They found significant negative relationships between career entrenchment and performance, as well as between continuance commitment and performance. One possible explanation is that the worker entrenched in his career does not see his activities as a means to prominence or better results, which leads to lower performance. 
With respect to this research agenda involving continuance commitment and career entrenchment, there are several points: both constructs have a similar theoretical basis - Becker (1960) -, they present similar sub-dimensions as well (personal sacrifices / accumulated costs and limited alternatives); both represent the individual's attitude toward a behavior (in this case, remaining in the organization), constituting a material bond and a permanence by necessity; both present positive correlations between themselves (CARSON et al., 1995; SCHEIBLE et al. 2013) and negative ones with variables such as performance (COOPER-HAKIM; VISWESVARAN, 2005; LAPOINTE; VANDENBERGHE; PANACCIO, 2011; SCHEIBLE et al., 2013; SCHEIBLE; BASTOS, 2014), considered to be desirable worker behaviors. Such aspects allow us to question whether these constructs might not be referring to a single psychosocial phenomenon. Would it be possible to affirm that continuance commitment is the same as entrenchment?

The question about the possible overlap of the constructs came from Blau (2001), who raised the possibility of integrating them. Based on the similarity between the subdimensions of continuance commitment and the dimensions of career entrenchment, Blau and Holladay (2006) conducted a study seeking to integrate the two constructs. To do so, they used the entrenchment scale developed by Carson et al. (1995) as a measure of continuance commitment, and adapted the scale of Meyer et al. (1993) as a measure of the affective and normative bases. The study results provide support for a four-dimensional measure of commitment, with the inclusion of the limited alternatives dimension, but it does not offer a verdict on separating continuance commitment into "accumulated costs / personal sacrifices" and "limited alternatives", since no comparison was made with the Meyer et al. (1993) continuance basis scale. The authors also suggest that correlations with antecedent and consequent variables of commitment be evaluated.

Scheible et al. (2013) question whether, instead of integrating the bases of entrenchment with commitment, it wouldn't be more appropriate to reconstruct the concept that currently incorporates antagonistic bases (affective $x$ continuance), since they have different natures and opposite behaviors in relation to different variables (MEYER et al., 2002; COOPER-HAKIM; VISWESVARAN, 2005; KLEIN et al., 2012; MOSCON; BASTOS; JANISSEK-DE-SOUZA, 2012). They propose, therefore, the integration of the subdimensions of continuance commitment with entrenchment. In this case, would it be possible to affirm that entrenchment represents the individual's instrumental bond with his career or even with the organization, while commitment refers to an affective connection?

In the present study, the links with the organization are the focus of the analysis. In Figure 1, the hypothetical model of this study is presented, which also aims, based on the hypothesis of overlap between organizational entrenchment and the continuance basis, to discuss the possibility that this instrumental dimension set aside integrating the concept of commitment, for the sake of greater accuracy. To test the similarity of the constructs, two structural models of overlap will be evaluated, considering the two-dimensional and three-dimensional structures of entrenchment, following the recommendation of Rodrigues and Bastos (2012). 


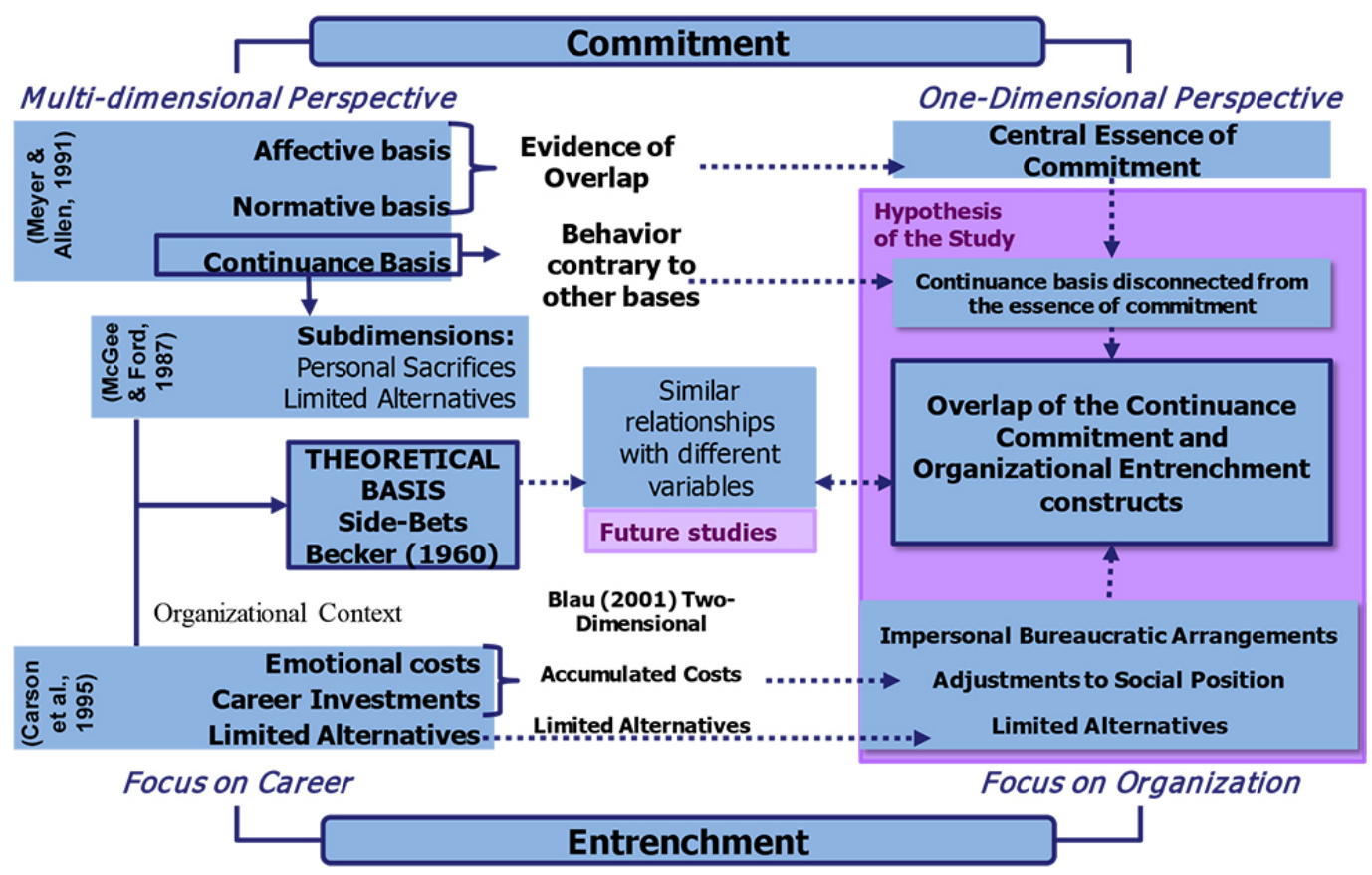

Figure 1 - Hypothetical model of the present study

Source: Prepared by the authors.

Note: Arrows with solid lines represent statements based on the literature reviewed; arrows with dashed lines represent interpretations and hypotheses of the present work.

\section{METHOD}

To test the hypothesis of overlap between continuance commitment and organizational entrenchment, an extensive cross-sectional study was carried out, which included a sample of 721 Brazilian workers. No prior sample calculation was performed and the questionnaire was made available to the respondents by accessibility criteria. As inclusion criteria, participants were required to have some formal employment relationship and be at least 18 years old. The tests indicated deviations from normality, with skewness to the right in the case of mean values for commitment (tendency to higher means).

The data collection instrument included: a structured questionnaire containing the organizational entrenchment scale (RODRIGUES; BASTOS, 2012) composed of three factors, Adjustments to Social Position (ASP), Limited Alternatives (LA), and Impersonal Bureaucratic Arrangements (IBA); and the continuance basis of the organizational commitment measure validated by Bastos et al. (2011) for the Brazilian context. Responses were based on a six-point Likert scale (totally disagree - totally agree).

Different strategies were used to make the collection possible in different contexts, and with the largest number of respondents: $83.6 \%$ of the respondents answered printed questionnaires, self-administered, $6.1 \%$ completed the digital version of the questionnaire via e-mail, and $7.6 \%$ of the respondents were interviewed. The interviews, which targeted workers with lower education levels, were supported by visual aids for a better understan- 
ding of the questions. In this case, an image with six columns was used, in the colors of red (column completely colored red for totally disagree, $2 / 3$ red and $1 / 3$ white for strongly disagree, $1 / 3$ red and $2 / 3$ white for mildly disagree) and green ( $1 / 3$ green and $2 / 3$ white for mildly agree, $2 / 3$ green and $1 / 3$ white for strongly agree, and completely green for totally agree), and the participant was asked to point to the answer chosen on each question.

For tabulation and analysis of the data, the SPSS 13.0 and AMOS 16.0 statistical softwares were used. Structural equation modeling was used to test the models of covariance between the continuance basis and entrenchment, considering both its three-factor and its two-factor structures. The Maximum Likelihood (ML) estimation method was used, given the sample size and the moderately nonnormal character of the data. In order to evaluate model fit, the following indices and criteria were considered: comparative fit indices (NFI Normed Fit Index, IFI - Incremental Fit Index, CFI - Comparative Fit Index, which should be greater than 0.90, and RMSEA - Root Mean Square Error of Approximation, which should be less than 0.08); indices of proportion of explained variance (GFI - Goodness of Fit Index and AGFI - Adjusted Goodness of Fit Index, expected above 0.90); indices of parsimony (PGFI - Parsimonious Goodness of Fit Index, which should be close to 1.0, AIC - Akaike Information Criterion and CAIK - Consistent Akaike Information Criterion, which should have smaller values than the competing model); and Residual-based Fit Index (RMR, which should present small values).

\section{RESULTS}

Of the total number of respondents, $82.3 \%$ live in Northeastern Brazil and $66 \%$ work in private companies, mainly in services $(30.3 \%)$, commerce $(22.8 \%)$, or industries (13.2\%). Participant characteristics include: just over half female (55.3\%), unmarried $(49.4 \%)$, and under the age of thirty-five (59.2\%). With regard to schooling, the vast majority had begun at least undergraduate level studies (71.9\%). With regard to monthly income, $19.9 \%$ receive less than minimum wage, and a large part of the sample $(48.9 \%)$ are paid in the range from one to five times minimum wage, calculated on the basis of the current value during the data collection period.

Initially, the three-factor model of organizational entrenchment and continuance commitment was tested. For the specification, all the relationships added in the original validations of the measures were considered (BASTOS et al., 2011; RODRIGUES; BASTOS, 2012).

Two items, originally elaborated by Meyer and Allen (1993) and by Rego (2003) to measure continuance commitment, remained in the "Limited Alternatives" dimension during the validation process for the entrenchment scale by Rodrigues and Bastos (2012). These same items compose the measure of the continuance basis validated by Bastos et al. (2011) for the Brazilian context. In view of this fact, it was necessary to establish parameters that would provide the explanation of these two items (IL2 and IL4, respectively) by the latent variables "limited alternatives" and "continuance commitment". Despite jeopardizing discriminant validity, such a measure was necessary, since these variables represent the perception of limited alternatives, which is present in the definition of both constructs. 
The initial model is over-identified and was tested with 312 degrees of freedom. The fit indices did not reach a satisfactory level, but they approached the predefined standards (Table 1). From the estimated parameters, the relationships between the errors for the IL2 and IL4 variables were not significant, nor between the latter and continuance commitment. All other coefficients, shown in parentheses in Figure 2, had high statistical significance.

The post hoc analyses of the model indicated the existence of a strong covariance between the disturbances of the latent variables "adjustments to social position" and "limited alternatives". Considering the high correlations obtained between ASP and LA during the exploratory analyses carried out by Rodrigues and Bastos (2012), in addition to the theoretical discussions that point to the complementarity of the two dimensions, it can be said that this covariance is coherent. Thus, respecting the theoretically and empirically justified recommendations, the modification was applied.

The fit indices obtained for the respecified model were better (Table 1), although they did not reach all the desired levels. The analysis of the modification indices and the matrix of residuals indicated that other parameters could be added to improve model fit, but there would be a risk of overfitting to the study sample due to the impossibility of testing the changes in a second independent sample. Therefore, it was considered more appropriate to maintain the model without additional respecifications.

Table 1 - Fit indices for the structural model of covariance between continuance commitment and organizational entrenchment (3 factors)

\begin{tabular}{|c|c|c|c|c|}
\hline Category & Index & Standard & Initial Model & Respecified Model \\
\hline \multirow{4}{*}{ Comparative fit indices } & NFI & At least 0.90 & 0.84 & 0.85 \\
\hline & IFI & At least 0.90 & 0.88 & 0.89 \\
\hline & $\mathrm{CFI}$ & At least 0.90 & 0.88 & 0.89 \\
\hline & RMSEA & $<0.08$ & 0.05 & 0.05 \\
\hline \multirow{2}{*}{$\begin{array}{l}\text { Indices of proportion of } \\
\text { explained variance }\end{array}$} & GFI & At least 0.90 & 0.90 & 0.91 \\
\hline & AGFI & At least 0.90 & 0.89 & 0.89 \\
\hline Residual-based fit indices & RMR & Small values & 0.12 & 0.11 \\
\hline \multirow{3}{*}{$\begin{array}{l}\text { Indices of parsimony of the } \\
\text { model tested }\end{array}$} & PGFI & Close to 1.0 & 0.75 & 0.75 \\
\hline & AIC & \multirow{2}{*}{ Small values } & $1104.02(16.98)^{*}$ & $1050.49(15.92)^{*}$ \\
\hline & CAIC & & $1466.76(22.57)^{*}$ & $1418.82(21.50)^{*}$ \\
\hline \multicolumn{3}{|c|}{$\chi^{2}(p<.01)$} & $974.015(\mathrm{DF}=313)$ & $918.495(\mathrm{DF}=312)$ \\
\hline
\end{tabular}

Source: Study data.

Note: * ratio between the index values and number of parameters estimated.

All parameters estimated for this second model were significant (Figure 2), with regression coefficients ranging from 0.41 to 0.68 , except for the parameters between continuance commitment and items IL2 and IL4. Although significant, the relationships found between these variables were weak. These results indicate, perhaps, that items IL2 and IL4 are better explained by $L A$, and that continuance commitment refers more specifically to the 
idea of personal sacrifices related to leaving the organization, which reinforces the findings of previous research and the argument that "limited alternatives" are not a constituent of the continuance basis (CARSON; CARSON, 2002; MEYER et al., 2002; POWELL; MEYER, 2004).

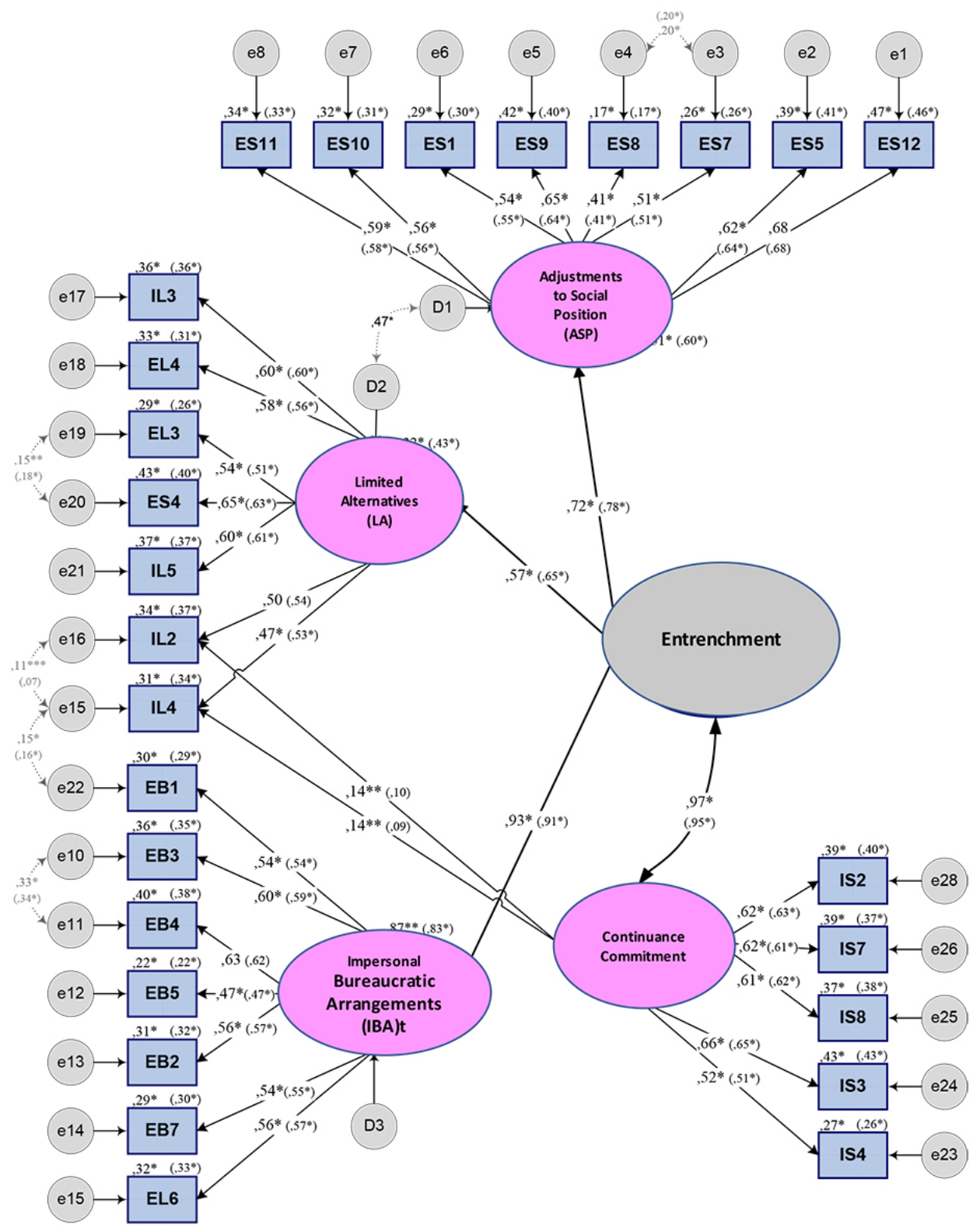

Figure 2 - Structural model of continuance commitment and organizational entrenchment ( 3 factors)

Source: Study data.

Note: ${ }^{*} p<.001 ;{ }^{* *} p<.01 ;{ }^{* *} p<.05$. In parentheses, data from the initial model.

Legend of acronyms: EB - Entrenchment, Bureaucratic Arrangements;

ES - Entrenchment, Adjustments to Social Position; EL - Entrenchment, Limited Alternatives;

$\mathrm{IL}$ - origin in the Instrumental basis measure, Limited Alternatives sub-dimension; IS - origin in the Instrumental basis measure, Sacrifices sub-dimension. 
The 0.47 correlation between the ASP and LA factors confirms that this parameter among the variables is indispensable for the good fit of the model, besides being another indication of overlap. An analysis of the standardized matrix of residuals reveals that there are still many residuals between the variables of these two dimensions, which means that newly inserted covariates would improve the fit indices.

Finally, the 0.97 correlation between continuance commitment and organizational entrenchment corroborates the hypothesis that the constructs are related to the same psychosocial phenomenon. It is not possible to guarantee, when analyzing this model in isolation, that the results were not affected by the existence of two items in common for the constructs (IL2 and IL4), even though they had low correlations with continuance commitment. For a safer assertion in this regard, the analysis of the structural model of correlation with the two-dimensional model of entrenchment is illuminating, since the LA dimension is not present.

The specification of the structural model of correlation between continuance commitment and two-factor organizational entrenchment also included all the parameters added during their validations. With 22 observable variables and 50 specified parameters, the model is estimable, with 203 degrees of freedom.

The fit indices obtained are satisfactory (Table 2), and only the NFI was below the desired value. Nevertheless, the other comparative fit indices are sufficient to affirm that the model presents a good fit in relation to others that could be specified with these same variables, with a greater or lesser number of parameters. The GFI and the AGFI indicate that the estimated population matrix from the relationships plotted for the model satisfactorily explains the variance of the sample correlation matrix. The RMR, which does not have a statistically established cutoff point, presented a low value. Inspection of the standardized matrix of residuals reveals high residuals all the same, especially among the variables of continuance commitment and organizational entrenchment. The analyses of post hoc modification complement this observation by pointing out the existence of covariance between items from the two constructs.

Table 2 - Fit indices for the structural model of covariance between continuance commitment and organizational entrenchment (2 factors)

\begin{tabular}{c|c|c|c|c|c|c}
\hline \multicolumn{4}{c|}{ Comparative fit indices } & \multicolumn{2}{|c}{$\begin{array}{c}\text { Indices of proportion of } \\
\text { explained variance }\end{array}$} & $\begin{array}{c}\text { Residual-based fit } \\
\text { indices }\end{array}$ \\
\hline NFI & IFI & CFI & RMSEA & GFI & AGFI & RMR \\
\hline 0.86 & 0.90 & 0.90 & 0.05 & 0.93 & 0.91 & 0.10 \\
\hline
\end{tabular}

Source: Study data.

The parameters observed in the structural model are all highly significant (Figure 3 ). The regression coefficients ranged from 0.41 to 0.68 , and the explained variances were from 0.17 to 0.46 , with only those whose variables showed covariance between the errors being lower. Entrenchment strongly explained the two sub-dimensions and showed a strong 
and significant correlation with continuance commitment (0.99), again confirming the hypothesis of overlap of the constructs.

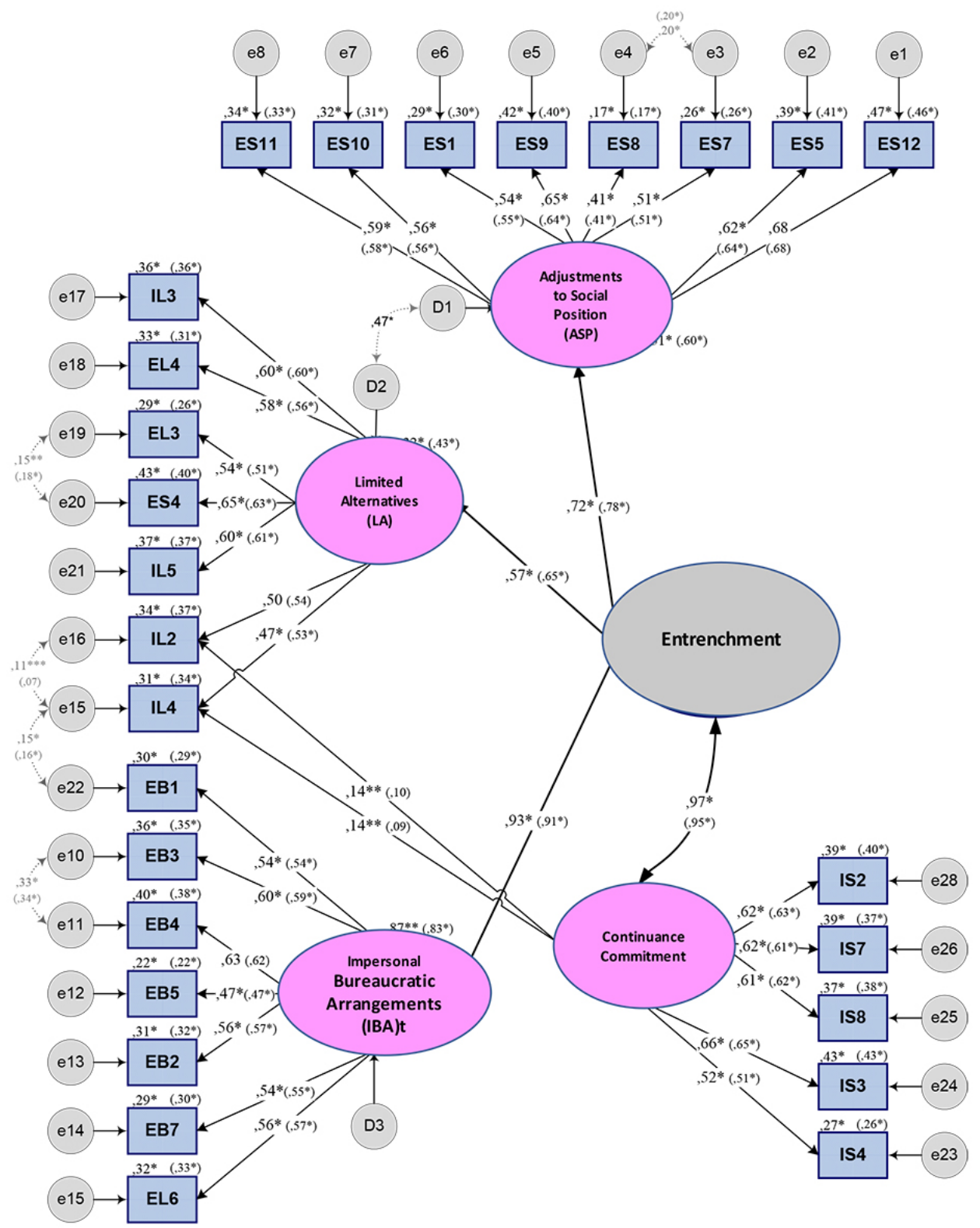

Figure 3 - Structural model of continuance commitment and organizational entrenchment (2 factors)

Source: Study data.

Note: ${ }^{*} p<.001$.

It is emphasized that in this model, because there is no LA dimension, the variables IL2 and IL4 represent pure indicators, that is, they are linked only to continuance commitment. Thus, it can be affirmed that the correlation between the continuance basis and organizational entrenchment obtained previously for the three-factor model was not affected 
by the variables in common between the constructs, since the correlation obtained in the two-factor model was equally strong. It is interesting to note in this model that although the IL2 and IL4 variables have obtained significant coefficients of determination, they are noticeably lower than those presented by the other variables, whose content is linked to the notion of "personal sacrifices". In line with the results found so far, this is another sign that the items referring to the perception of limited alternatives stand out from those related to personal sacrifices.

In Table 3, the fit indices of the two models treated here are compared. It is observed that the differences between the indicators, in general, do not exceed the value of 0.01 , considered too low to affirm that one of these is more adequate. Even the parsimony indices of the model have very close values, being slightly higher for the three-dimensional model, which is also the more complex and therefore less parsimonious. In addition, the fact that there is no standardization for the AIC and for the CAIC does not allow us to identify if the difference is enough to consider one of the two models better than the other.

Table 3 - Comparison of fit indices of structural models of covariance between continuance commitment and organizational entrenchment

(three-factor and two-factor)

\begin{tabular}{|c|c|c|c|c|}
\hline \multirow[t]{2}{*}{ Category } & \multirow[t]{2}{*}{ Index } & \multirow[t]{2}{*}{ Standard } & $\begin{array}{c}\text { Continuance Commit- } \\
\text { ment and Organizational } \\
\text { Entrenchment }\end{array}$ & $\begin{array}{c}\text { Continuance Commit- } \\
\text { ment and Organizational } \\
\text { Entrenchment }\end{array}$ \\
\hline & & & 3-Factor Model & 2-Factor Model \\
\hline \multirow{5}{*}{ Comparative fit indices } & NFI & At least 0.90 & 0.85 & 0.86 \\
\hline & IFI & At least 0.90 & 0.89 & 0.90 \\
\hline & $\mathrm{CFI}$ & At least 0.90 & 0.89 & 0.90 \\
\hline & RMS & \multirow{2}{*}{$<0.08$} & \multirow{2}{*}{0.05} & \multirow{2}{*}{0.05} \\
\hline & $E A$ & & & \\
\hline \multirow{2}{*}{$\begin{array}{l}\text { Indices of proportion of } \\
\text { explained variance }\end{array}$} & GFI & At least 0.90 & 0.91 & 0.93 \\
\hline & AGFI & At least 0.90 & 0.89 & 0.91 \\
\hline $\begin{array}{l}\text { Residual-based fit } \\
\text { indices }\end{array}$ & RMR & Small values & 0.11 & 0.10 \\
\hline \multirow{3}{*}{$\begin{array}{l}\text { Indices of parsimony of } \\
\text { the model tested }\end{array}$} & PGFI & Close to 1.0 & 0.75 & 0.74 \\
\hline & AIC & \multirow{2}{*}{ Small values } & 1050.5 (15.9) & $726.356(14.5)$ \\
\hline & CAIC & & $1418.8(21.5)$ & $1005.388(20.1)$ \\
\hline \multicolumn{3}{|c|}{$\chi^{2}(p<.001)$} & $918.495(\mathrm{DF}=312)$ & $626.356(\mathrm{DF}=203)$ \\
\hline
\end{tabular}

Source: Study data.

Note: Ratio between index values and number of parameters estimated.

Some aspects observed in the models should be emphasized. In both cases, the analysis of the matrix of residuals and the indicators of post hoc modification pointed to the possibility of improving the fit indices, through the addition of parameters between the continuance commitment and organizational entrenchment variables. In general, a greater 
number of residuals is an indication that the model has not yet achieved the most appropriate fit (ULLMAN, 2007). However, the objective of this work is not to present the best model of correlation between the constructs, but rather to provide conceptual and empirical evidence that we are dealing with a single construct. Thus, in addition to the high correlations found in the two models tested, the residuals and indicators of change that point to strong covariance between the variables of the two constructs are also considered signs of overlap.

It is also worth noting that the three-dimensional model used for the comparison contains the parameter between the disturbances of the LA and ASP factors. Although there is a theoretical justification for maintaining the three dimensions of organizational entrenchment (RODRIGUES; BASTOS, 2012), the empirical results cannot be ignored. Quintana and Maxwell (1999) provide for this type of situation in using the structural equation modeling technique, when competing models have fit indices and parameter values that are close, and theoretical arguments are not sufficient to define the best model. It is important to emphasize, however, that the dimensionality of organizational entrenchment does not interfere in the results that point to its empirical overlap with continuance commitment.

It is also possible to state that the results found after testing the models provide support for Osigweh's (1989) thesis on the stretching of "organizational commitment" and the hypothesis that part of the construct - the continuance basis - may be better explained by the concept of organizational entrenchment. Thus, it is concluded that the measure of organizational entrenchment guarantees a greater sophistication and theoretical density for the phenomenon of permanence by necessity, which is now also being treated as part of organizational commitment.

\section{CONCLUSIONS AND IMPLICATIONS OF THE STUDY}

The present study sought to gather theoretical arguments and empirical evidence to support that organizational entrenchment and continuance commitment represent the same psychosocial phenomenon. The results presented confirmed this hypothesis, which reinforces the idea that they represent, in fact, one single construct, distinct from commitment.

In view of the recommendation of Rodrigues and Bastos (2012) for the evaluation of the two structures of the organizational entrenchment measure, both possibilities were considered. Again, the models presented similar characteristics and it was not possible to aggregate information about the dimensionality of the construct. Despite this, the primary evidence of overlap between continuance commitment and organizational entrenchment was presented: high correlation coefficient, which is indicative of redundancy, and a large amount of indices of modification and residuals between the variables of the two constructs, which means, in structural equation modeling, that many relationships would need to be specified between these items in order for the models to attain the most appropriate fit. The need to trace these parameters stems from the strong correlations in the sample data matrix, which is another indication of overlap.

A single study is not enough to disintegrate a concept and to detach one of its dimensions, since, in addition to the possible existing limitations, other delineations and alternatives of discriminant validity evaluation are needed to compose an empirical basis that 
could support such a decision. With this caveat, it can be said that this work fulfills the role of presenting consistent empirical evidence to reinforce the efforts for greater delimitation for the concept and the study of organizational commitment. It is concluded that the proposal to adopt the concept of commitment in the one-dimensional perspective has empirical support and can contribute to the advancement of this field of study.

Some limitations may be emphasized as a starting point for a cautious treatment of the results presented here and for the improvement of future investigations. The sample collected and used for analysis is composed mostly of young workers with advanced education levels. It is possible that these characteristics may have affected the results, since, as stated by Laros (2005), more accurate results of correlations between variables are guaranteed by a greater variability of the sample. In addition, violations of data normality, although common in studies in the social sciences and in research with objects of studies influenced by social desirability, may have affected the results obtained for the fit indices and for the matrices of residuals of the models tested (FU; DESHPANDE, 2012).

In addition, the results can be analyzed in light of the influences of Brazilian culture. Wasti et al. (2016) emphasize that, despite the importance of developing global concepts of attachments to work that facilitate the advancement of knowledge in the field, one cannot lose sight of the necessary care when applying such models, conceived in one culture, to another whose peculiarities can significantly alter the measures.

Given the relevance of carefully examining the possible overlap between continuance commitment and organizational entrenchment, it is recommended that the present work be replicated in distinct samples. One alternative way of investigating the overlap between the constructs is to compare their explanatory models of antecedent, correlated, and consequent variables in order to obtain information about their discriminant validity. New exploratory analyses with the organizational entrenchment items, including the items of continuance commitment, may provide new indications about the patterns of relationships between the variables of the constructs, in addition to those obtained in the present work. Delineations from qualitative research could contribute to exploring the delimitations between the concepts through the understanding of the factors considered by individuals in the decision-making process for remaining or not in the organization. Intensive studies with workers classified as entrenched / non-entrenched, committed / non-committed could also assist in the conceptual delimitation between the constructs.

In view of the debates waged by the studies about bonds, especially in relation to the problems presented by organizational commitment, it is hoped that the present work will be part of the new directions in research on the bonds between the individual and the organization, helping to minimize conceptual redundancy and the empirical problems that the studies supported by the three-dimensional model of commitment have accumulated over the last decades.

\section{REFERENCES}

ALLEN, N. Commitment as a multidimensional construct. In: MEYER, J.P. (ed.). Handbook of Employee Commitment. Cheltenham, UK: Edward Elgar Publishing, 2016. 
ALUTTO, J.A. et al. On operationalzing the concept of commitment. Social Forces, v 51, p. 448-454, 1973.

BASTOS, A.V.B. et al. Vínculos dos indivíduos com a organização: análise da produção científica brasileira 2000-2010. Psicologia: Teoria e Pesquisa, v. 30, n. 2, p. 153-162, 2014.

. Comprometimento no trabalho: fundamentos para a gestão de pessoas. In: BORGES, L.O.; MOURÃO, L. (eds.). 0 trabalho e as organizações: intervenções a partir da Psicologia. Porto Alegre: Artmed, 2013.

. Comprometimento organizacional: aprimoramento e evidências de validade do modelo tridimensional de Meyer e Allen no contexto brasileiro. In: ZANELLI, J.C.; SILVA, N.; TOLFO, S.R. (eds.). Processos psicossociais nas organizações e no trabalho. São Paulo: Casa do Psicólogo, 2011, p.145-160.

BLAU, G.; HOLLADAY, E.B. Testing the discriminant validity of a four-dimensional occupational commitment measure. Journal of Occupational and Organizational Psychology, United Kingdom, v. 79, n. 4, p. 691-704, 2006.

BECKER, H.S. Notes on the concept of commitment. The American journal of Sociology, v. 66, p. 32-40, 1960.

BLAU, G. On assessing the construct validity of two multidimensional constructs: occupational commitment and occupational entrenchment. Human Resource Management Review, v. 11, 279-298, 2001.

BUCHANAN, B. Building organizational commitment: The socialization of managers in work organizations. Administrative Science Quarterly, v. 19, p. 533-546, 1974.

CARSON, K.; BEDEIAN, A. Career commitment: construction of a measure and examination of its psychometric properties. Journal of Vocational Behavior, v. 44, p. 237-262, 1994.

CARSON, K.D. et al. Development and construct of a career entrenchment measure. Journal of Occupational and Organizational Psychology, v. 68, p. 301-320, 1995.

CARSON, K.D.; CARSON, P.P. Differential relationships associated with two distinct dimensions of continuance commitment. International Journal of Organization Theory and Behavior, v. 5, n. 3, p. 359-381, 2002.

COOPER-HAKIM, A.; VISWESVARAN, C. The construct of work commitment: testing an integrative framework. Psychological Bulletin, v. 131, n.2, p. 241-259, 2005.

ETZIONI, A. Análise comparativa de organizações complexas. Editora da Universidade de São Paulo: São Paulo, SP, 1974.

. A comparative analysis of complex organizations: On power, involvement, and their correlates. New York: Free Press of Glencoe, 1961.

FU, W.; DESHPANDE, S. Antecedents of Organizational Commitment in a Chinese Construction Company. Journal of Business Ethics, v. 109, p. 3, p. 301-307, 2012.

KANTER, R.M. Commitment and social organization: a study of commitment mechanisms in utopian communities. American Sociological Review, v. 33, n. 4, p. 499-517, 1968. 
KLEIN, H.J. Distinguishing commitment bonds from other attachments in a target-free manner. In: FORD, J.K.; HOLLENBECK, J.R.; RYAN, A.M. (eds.). The Nature of Work: Advances in Psychological Theory, Methods, and Practice. Washington, DC: American Psychological Association Press, 2013, p. 117-146.

KLEIN, H.J.; PARK, H.M. Commitment as a unidimensional construct. In: MEYER, J.P. (ed.). Handbook of Employee Commitment. Cheltenham, UK: Edward Elgar Publishing, 2016.

KLEIN, H.J. et al. The Assessment of Commitment: Advantages of a Unidimensional, Target-Free Approach. Journal of Applied Psychology, v. 99, n. 2, p. 222-238, 2014.

. Reconceptualizing workplace commitment to redress a stretched construct: revisiting assumptions and removing confounds. Academy of Management Review, v. 37, n. 1, p. 130-151, 2012.

LAPOINTE, E.; VANDENBERGHE, C.; PANACCIO, A. Organizational commitment, organization-based self-esteem, emotional exhaustion and turnover: A conservation of resources perspective. Human Relations, v. 64, p. 1609-1631, 2011.

LAROS, J.A. O uso da análise fatorial: algumas diretrizes para pesquisadores. In: PASQUALI, L. (org.). Análise fatorial para pesquisadores. Brasília: LabPAM, 2005.

MAGALHÃES, M. Valores pessoais, vínculos com a carreira e comprometimento organizacional. Interação em Psicologia, v. 17, n. 2, 2014.

MAGALHÃES, M.O. Generatividade e vínculos com a carreira e com a organização: problematizando as bases do comprometimento organizacional. Revista Brasileira de Orientação Profissional, v. 9, p. 67-80, 2008.

MAGALHÃES, M.O.; GOMES, W.B. Personalidades vocacionais, generatividade e carreira na vida adulta. Revista Brasileira de Orientação Profissional, v. 6, n. 2, p. 71-80, 2005.

MEYER, J.P. Handbook of Employee Commitment. Cheltenham, UK: Edward Elgar Publishing, 2016.

MEYER, J.P.; ALLEN, N.J. A three-component conceptualization of organizational commitment. Human Resource Management Review, v. 1, n.1, p. 61-89, 1991.

MEYER, J.P. et al. Commitment to organizations and occupations: extension and test of a three-component conceptualization. Journal of Applied Psychology, v. 78, n. 4, p. 538551, 1993.

. Affective, Continuance, and Normative Commitment to the Organization: A Meta-analysis of Antecedents, Correlates, and Consequences. Journal of Vocational Behavior, v. 61, p. 20-52, 2002.

MOSCON, D.C.B.; BASTOS, A.V.B.; JANISSEK-DE-SOUZA, J. É possível integrar, em um mesmo conceito, os vínculos afetivo e instrumental? O olhar de gestores sobre o comprometimento com a organização. Organizações \& Sociedade, v. 19, n. 61, p. 357-373, 2012.

MOWDAY, R.T. et al. Employee-organization linkages: the psychology of commitment, absenteeism, and turnover. New York: Academic Press, 1982. 
O'REILLY, C.; CHATMAN, J. Organizational commitment and psychological attachment: the effects of compliance, identification, and internalization on prosocial behavior. Journal of Applied Psychology, v. 71, n. 3, p. 492-499, 1986.

OSIGWEH, C.A.B. Concept fallibility in organizational science. Academy of Management. The Academy of Management Review, v. 14, n. 4, p. 579-594, 1989.

PORTER, L.W.; STEERS, R.M.; MOWDAY, R.T. Organizational commitment, job satisfaction and turnover among psychiatric technicians. Journal of Applied Psychology, v. 59, n. 5, p. 603-609, 1974.

POWELL, D.M.; MEYER, J.P. Side-bet theory and the three-component model of organizational commitment. Journal of Vocational Behavior, v. 65, p. 157-177, 2004.

QUINTANA, S.M.; MAXWELL, S.E. Implications of recent developments in structural equation modeling for counseling psychology. The Counseling Psychologist, v. 27, n. 4, p. 485-527, 1999.

REGO, A. Comprometimento Organizacional e Ausência Psicológica: afinal, quantas dimensões? Revista de Administração de Empresas, v. 45, n. 4, p. 25-35, 2003.

REICHERS, A.E. A review and reconceptualization of organizational commitment. Academy of Management Review, v. 10, n. 3, p. 465-476, 1985

RODRIGUES, A.C.A.; BASTOS, A.V.B. Entrincheiramento organizacional: construção e validação da escala. Psicologia: Reflexão e Crítica, v. 25, n. 4, p. 688-700, 2012.

. Entrincheiramento Organizacional: proposta de um novo vínculo indivíduo-organização. In: ZANELLI, J.C.; SILVA, N.; TOLFO, S.R. (eds.). Processos psicossociais nas organizações e no trabalho. São Paulo: Casa do Psicólogo, 2011, p. 161-178.

. Problemas conceituais e empíricos na pesquisa sobre comprometimento organizacional: uma análise crítica do modelo tridimensional de J. Meyer e N. Allen. Revista de Psicologia Organizacional e do Trabalho, v. 10, n. 2, p. 129-144, 2010.

RODRIGUES, A.C.A.; CARVALHO-FREITAS, M.N. Theoretical fragmentation: Origins and repercussions in Work \& Organizational Psychology. Revista Psicologia: Organizações e Trabalho, v. 16, p. 310-3015, 2016.

SCHEIBLE, A.C.F.; BASTOS, A.V.B. Analyzing the Impacts of Commitment and Entrenchment on Behavioral Intentions. Universitas Psychologica, v. 13, n. 1, p. 109-119, 2014.

SCHEIBLE, A.C.F. et al. Comprometimento e entrincheiramento na carreira: integrar ou reconstruir os construtos? Uma exploração das relações à luz do desempenho. Revista de Administração, v. 48, n. 3, p. 530-543, 2013.

SOLINGER, O.N. et al. Beyond the three-component model of organizational commitment. Journal of Applied Psychology, v. 93, n. 1, p. 70-83, 2008.

ULLMAN, J.B. Structural equation modeling. In: TABACHNICK, B.G.; FIDELL, L.S. Using Multivariate Statistics. EUA: Pearson Education, 5a. ed, 2007.

WASTI, S.A. et al. Location, location, location: Contextualizing workplace commitment. Journal of Organizational Behavior, n. 37, p. 613-632, 2016. 
WIENER, Y. Commitment in organizations: a normative view. Academy of Management Review, v.7, 1982.

Submission date: 04/04/2017.

Approval date: 20/12/2017. 